\title{
Effect of Soaking Time of Bamboo Shoot and Concentrations of Lime Paste on Quality of Bamboo Shoot Chips
}

\author{
Herda Harvina $^{1 *}$, Rahmat Afrizal ${ }^{1}$, Fadlan Hidayat ${ }^{2}$ \\ ${ }^{1}$ Department of Industrial Engineering Agriculture, Serambi Mekkah University \\ ${ }^{2}$ Department of Food Technolgy, Serambi Mekkah University \\ *Email : herda.hervina1@gmail.com
}

\section{Article Info \\ Article history \\ Received: \\ 05/20/2019 \\ Received in revised: \\ 05/21/2019}

Accepted:

$05 / 22 / 2019$

\begin{abstract}
The aim of this reserch are to deteremine the effect of lime paste concentration and time soaking, to determine the best condition of making bamboo shoot chips. The resuls of analysis were processed by using Completely Randomized Design factorial with two repeatation. The lowest water content obtained at the condition of concentration of lime paste of 3\% (K2) dan time soaking (L1) of 15 minutes is 4,03 . While, the lowest ash content obtained at the concentration of lime paste (K3) of 5\% dan soaking time (L3) of 25 minutes is 3,63 . The best organoleptic of taste was obtained at concentration of lime paste (K3) of 5\% and soaking time (L3) of 25 minutes that was 6,80 . The best organoleptic of flavour was obtained at concentration of lime paste (K2) of $3 \%$ and soaking time (L2) of 20 minutes that was 6,07. While, the best organoleptic of texture was obtained at concentration of lime paste (K3 and K2) of $3 \%$ and $5 \%$ and soaking time (L1) of 15 minutes that was 3,04.
\end{abstract}

Keywords: Chip, Bamboo Shoot, Concentration of Lime Paste, Soaking Time.

\section{Pengaruh Lama Perendaman Rebung Bambu Dalam Larutan Kapur Sirih Dengan Konsentrasi Yang Berbeda Terhadap Mutu Keripik Rebung}

\begin{abstract}
Abstrak
Tujuan penelitian ini ialah untuk mengetahuai pengaruh konsentrasi kapur sirih dan lama perendaman, untuk menentukan perlakuan terbaik dan pengaruh variabel pada pengolahan keripik rebung bambu. Data hasil penelitian diolah dengan menggunakan Rancangan Acak Lengkap (RAL) Faktorial dengan 2 ulangan, analisis data dengan ANOVA dan Uji Lanjut Beda Nyata Terkecil (BNT). Perlakuan terbaik kadar air terdapat pada konsentrasi kapur sirih 3\% (K2) dan lama perendaman 15 menit (L1) sebesar 4,03. Sedangkan kadar abu terendah terdapat pada konsentrasi kapur sirih 5\% (K3) dan lama perendaman 25 menit (L3) yaitu 3,63. Uji organoleptik keripik rebung terhadap aroma terbaik adalah pada penambahan kapur sirih 3\% (K2), dan lama perendaman (L3) yaitu sebesar 6,80, organopletik rasa terbaik terdapat pada penambahan konsentrasi kapur sirih 3\% (K2) dan lama perendaman 20 menit (L2) sebesar 6,07, dan organoleptik tekstur pada penambahan kapur sirih 3\% (K2) dan 5\% (K3) dan lama perendaman selama 15 menit (L1) yaitu sebesar 3,04.
\end{abstract}

Kata kunci: Keripik, Rebung, Konsentrasi Kapur Sirih, Lama Perendaman 


\section{PENDAHULUAN}

Rebung merupakan tunas muda dari tanaman bambu yang hidup pada permukaan dasar rumpun biasanya dipenuhi oleh glugut (rambut bambu) yang gatal. Tanaman ini dapat hidup di daerah dataran rendah sampai daerah dengan ketinggian 300 meter di bawah permukaan laut, di tempat terbuka dan bebas genangan air (Rizkiyani N., dkk, 2016). Rebung bambu mempunyai morfologi yang berbentuk kerucut, pada ujung glugut memiliki bagian seperti ujung daun bambu yang berwarna cokelat. Musim hujan merupakan waktu yang sesuai untuk panen raya rebung untuk rebung sudah mencapai tingginya sekitar $20 \mathrm{~cm}$ dari permukaan tanah dan diameter batang sekitar $7 \mathrm{~cm}$ (https://www.kompasiana.com/wurie-

hadi/rebung-sumber-pangan-bersahabat-dimusim-yang-tak-bersahabat). Pemanenan rebung tersebut dapat dilakukan sepanjang tahun.

Rebung sudah telah lama dimanfaatkan sebagai bahan dalam sayuran. Rebung kaya akan nutrisi seperti serat dan kalium. Kandungan serat pangan pada rebung juga cukup baik yaitu sekitar 2,56 persen (Astawan, 2008). Kandungan seratnya tersebut baik jika dikonsumsi untuk melancarkan pencernaan. Selain itu, rebung juga mengandung kadar kalium cukup tinggi yaitu setiap 100 gram rebung terkandung kadar kalium sekitar 533 mg (Pamungkas, 2009). Kalium merupakan zat mikro yang memiliki kemampuan untuk mengurangi resiko penyakit stroke (https://www.deherba.com/tahukah-andaberbagai-khasiat-rebung.html). Pengolahan rebung menjadi keripik rebung merupakan salah satu cara untuk mendapatkan manfaat gizi dari rebung.

Keripik adalah makanan ringan yang terbuat dari potongan atau irisan buah- buahan atau sayuran yang kemudian dilakukan penggoreng pada suhu tertentu. Keripik merupakan makanan sederhana namun pengolahannya tidak sesederhana bentuknya. Ada

beberapa

kendala yang terjadi saat pembuatan keripik, seperti warnanya menjadi tidak fresh, ukuran keripikyang mengecil atau tekstur yan tidak crunchy (renyah) (Nofrianti R., 2013). Pengolahan keripik harus dilakukan dengan baik sehingga tekstur, warna, citarasa dan kerenyahan dapat menghasilkan kualitas terbaik. Bahan yang lainnya dapat ditambahkan pada irisan buah atau sayur tersebut yang mempengaruhi mutu akhir (karakteristik) dari keripik yang dihasilkan.

Keripik yang renyah umumnya dilakukan dengan menambahkan larutan kapur sirih $\mathrm{Ca}(\mathrm{OH})_{2}$. Kapur sirih merupakan salah satu sumber ion kalsium yang relatif murah dan mudah didapat dipasaran dan sering digunakan pada pengolahan pangan untuk meningkatkan produk pangan. Pada pembuatan keripik, zat kalsium yang tertinggal dalam irisan buah akan membuat tekstur keripik menjadi keras. Menurut Suprapti (2005), kapur sirih merupakan firming agent, yaitu bahan kimia yang berfungsi sebagai pengeras jaringan bahan. Perendaman dalam kalsium hidroksida dapat menambah kerenyahan produk hasil penggorengan, karena dengan adanya penambahan kalsium hidroksida akan menghasilkan gas $\mathrm{CO}_{2}$ yang dapat membentuk pori-pori pada keripik, sehingga tekstur keripik yang dihasilkan akan semakin renyah. Perendaman dalam larutan kapur sirih $\mathrm{Ca}(\mathrm{OH})_{2}$ berfungsi untuk menguatkan tekstur buah yang diolah menjadi keripik sehingga kalsium dalam kapur sirih masuk ke dalam jaringan buah, sehingga tekstur 
jaringan buah menjadi lebih kompak dengan adanya ikatan baru antara kalsium dan jaringan buah.

Berdasarkan penelitian Munawar (2009) membuat keripik rebung dengan vacuum drying mendapatkan perlakuan terbaik pada perendaman kapur sirih yaitu 10 gram/Liter dan lama perendaman selama 20 menit. Konsentrasi kapur sirih dan lama perendaman menjadi faktor penting terhadap mutu keripik rebung. Oleh karena itu, pengaruh konsentrasi kapur sirih dan pengaruh lama perendaman rebung serta pengaruh interaksi keduanya terhadap mutu keripik rebung bambu menjadi permasalahan di dalam penelitian ini.

\section{METODE PENELITIAN}

\section{Bahan}

Bahan yang digunakan dalam penelitian ini adalah rebung bambu 200 gram yang telah diiris-iris, $\mathrm{Ca}(\mathrm{OH})_{2}(1 \%$, $3 \%, 5 \%)$, minyak goreng $1000 \mathrm{~mL}$, garam dapur $(\mathrm{NaCl})$ dan air.

\section{Alat}

Alat yang digunakan dalam penelitian ini adalah kompor gas, centong, wajan, pemarut, pisau, baskom, cawan aluminium.

\section{Pengumpulan Data}

Penelitian ini menggunakan Rancangan Acak Lengkap (RAL) faktorial dengan 2 ulangan konsentrasi kapur sirih (K) yang terdiri dari 3 level dan lama perendaman rebung (L) yang terdiri dari 3 level. Taraf perlakuan dari masing-masing faktor adalah sebagai berikut :Konsentrasi larutan kapur sirih $(\mathrm{K})$ yang terdiri dari 3 level yaitu: K1 : $1 \%, \mathrm{~K} 2: 3 \%, \mathrm{~K} 3: 5 \%$. Lama perendaman (L) yang terdiri dari 3 level yaitu: L1 : 15 menit, L2 : 20 menit,
L3 : 25 menit. Terdapat 9 kombinasi perlakuan dan ulangan sebanyak 2 (dua) kali sehingga jumlah perlakuan keseluruhnya 18 satuan percobaan.

\section{Prosedur Penelitian}

Adapun prosedur cara pembuatan keripik rebung adalah sebagai berikut: Pembuangan glugut rebung dilakukan dengan menggunakan pisau. Rebung yang telah dibersihkan glugutnya diiris dengan ukuran kurang lebih $2 \mathrm{~mm}$. Kemudian rebung direndam dengan larutan kapur sirih sesuai perlakuan yaitu $(1 \%, 3 \%, 5 \%)$ selama (15, 20, 25 menit). Rebus rebung yang telah diiris-iris minimal selama 10 menit. Setelah getah rebung hilang, irisan diangkat dan ditiriskan di bawah terik matahari selama 30 menit sampai tidak tampak basah (bukan kering). Kemudian ditambahkan garam. Disiapkan penggorengan dan dimasukkan minyak goreng untuk dipanaskan. Lalu, irisan rebung digoreng sambil dilakukan bolakbalik. Setelah warna keripik kekuningan dan teksturnya renyah, keripik diangkat dan dinginkan. Kemudian keripik rebung yang sudah digoreng dianalisa.

\section{Metode Analisa}

Pengamatan dan metode analisa terhadap parameter keripik rebung adalah sebagai berikut kadar air (SNI, 01-28911996), kadar abu (SNI, 01-2891-1996), dan uji organoleptik.

\section{HASIL DAN PEMBAHASAN \\ Kadar Air}

Kadar air sangat penting dalam menentukan daya awet dari bahan makanan karena mempengaruhi sifat fisik, kimia, perubahan mikrobiologi dan perubahan enzimatis. Kandungan air dalam bahan makanan ikut menentukan 
penerimaan konsumen, kesegaran dan daya tahan terhadap kerenyahan. Kandungan air yang tinggi dalam bahan menyebabkan daya tahan bahan rendah. Untuk memperpanjang daya tahan suatu bahan, sebagian air dalam bahan harus dihilangkan dengan berbagai cara tergantung dari jenis bahan.

Tabel 1. Rata-rata hasil analisa kadar air pada tiap taraf penambahan kapur sirih dan lama perendaman

\begin{tabular}{lccc}
\hline Konsentrasi & \multicolumn{3}{c}{ Lama Perendaman (Menit) } \\
\cline { 2 - 4 } Kapur & L1 (15) & L2 (20) & L3 (25) \\
Sirih (\%) & & & \\
\hline K1 (1 \%) & 36,67 & 11,74 & 19,06 \\
K2 (3\%) & 4,03 & 10,28 & 13,67 \\
K3 (5\%) & 18,27 & 26,01 & 27,13 \\
\hline
\end{tabular}

$\operatorname{BNT}(0,05 \%)=12,67$

Tabel 1 menunjukkan bahwa nilai rata-rata kadar air yang tertinggi yang terdapat pada keripik rebung adalah perlakuan penambahan kapur sirih $1 \%$ (K1) dan lama perendaman 15 menit (L1) sebesar $36,67 \%$. Nilai rata-rata kadar air terendah terdapat pada penambahan kapur sirih $3 \%$ (K2) dan lama perendaman selama 15 menit (L2) yaitu 4,03\%. Kadar air keripik rebung berkurang dari konsentrasi kapur sirih 1\% hingga 3\%. Kapur sirih berfungsi membentuk tekstur keras atau padat pada bahan makanan. Kandungan kalsium di dalam kapur sirih akan bereaksi dengan pati rebung, sehingga rebung akan bertekstur lebih padat (tidak lembek) dan kapur juga bersifat osmosis (meresap air). Selain itu, kapur sirih dapat mengurangi kadar getah pada rebung. Glikoprotein pada getah hilang dan glikoprotein bersifat mengikat kalsium sehingga air yang terkandung dalam bahan terikat dengan getah menjadi bebas dan air bebas lebih mudah dihilangkan (Siregar N.E., dkk, 2015). Jadi, semakin tinggi persentase kapur sirih yang ditambahkan pada larutan perendam maka kadar air semakin rendah.

Di dalam penelitian ini, analisa kadar air pada keripik rebung telah dilakukan pengujian berdasarkan Rancangan Acak Lengkap (RAL).

Tabel 2. Analisis Sidik Ragam

\begin{tabular}{ccccccc}
\hline SK & Db & \multirow{2}{*}{ JK } & KT & F hitung & \multicolumn{3}{c}{ F tabel } \\
\cline { 6 - 7 } Perlakuan & 8 & & & - & $\mathbf{0 , 0 5}$ & $\mathbf{0 , 0 1}$ \\
K & 2 & 769,04 & 384,52 & $12,26^{* *}$ & 4,26 & - \\
L & 2 & 57,92 & 28,96 & $0,923 T n$ & 4,26 & 8,02 \\
KL & 4 & 787,66 & 196,92 & $6,28^{*}$ & 3,63 & 6,42 \\
Galat & 9 & 282,24 & 31,36 & - & - & - \\
\hline Total & 17 & 1896,86 & - & - & - & - \\
\hline
\end{tabular}

Analisis sidik ragam Tabel 2. menunjukkan bahwa, pada perlakuan penambahan konsentrasi kapur sirih nilai $\mathrm{F}$ hitung yaitu 12,26 $\geq$ (lebih besar) dari pada nilai $F$ tabel 0,05 dan 0,01 yaitu 4,26 dan
8,02 maka dapat disimpulkan bahwa penambahan kapur sirih sangat berpengaruh nyata, sedangkan perlakuan lama perendaman nilai $\mathrm{F}$ hitung $0,923 \leq$ (lebih kecil) dari pada nilai $\mathrm{F}$ tabel 0,05 
dan 0,01 yaitu 4,26 dan 8,02 maka dapat disimpulkan bahwa lama perendaman tidak berpengaruh nyata terhadap kadar air, dan interaksi antara penambahan kapur sirih dan lama perendaman nilai $\mathrm{F}$ hitung yaitu 6,28 yaitu $\geq$ (lebih besar) dari pada nilai $\mathrm{F}$ tabel 0,05 dan 0,01 yaitu 3,63 dan 6,42 maka dapat disimpulkan bahwa interaksi antara keduanya berpengaruh nyata.

Dari analisis kadar air pada keripik rebung, parameter kadar air yang dihasilkan pada perlakuan penambahan kapur sirih 3\% (K2) dan lama perendaman 25 menit (L1) memiliki kadar air sebesar 4,03 sehingga dapat dinyatakan bahwa persentase kadar air memenuhi syarat mutu keripik SNI yang sudah ditetapkan yaitu maksimal $6,0 \%$.

\section{Kadar Abu}

Abu yaitu sisa yang tertinggal bila suatu sampel bahan makanan dibakar dengan sempurna didalam suatu tungku pengabuan. Kadar abu menggambarkan banyaknya mineral yang tidak dapat terbakar dari zat yang tidak dapat menguap (Soediaoetama, 2002). Di dalam penentuan kadar abu berhubungan dengan mineral suatu bahan, maka semakin banyak konsentrasi kapur sirih yang ditambahkan akan menyebabkan kadar abu semakin banyak (Siregar N.E., dkk., 2015). Di dalam penelitian ini, kadar abu mengalami penurunan dari lama perendaman $1 \%$ hingga 5\%. Hal ini disebabkan banyaknya komponen mineral dari larutan kapur yang kembali tertinggal pada larutan kapur. Pada konsentrasi larutan kapur $1 \%$, irisan rebung telah mencapai kejenuhan sehingga tidak mampu menyerap mineral dari larutan kapur sirih lagi. Hasil analisis kadar abu pada keripik rebung ditunjukkan dalam Tabel 3.
Nilai tertinggi kadar abu terdapat pada penambahan konsentrasi kapur sirih 1\% (K1) dan lama perendaman 15 menit (L1) sebesar 7,91. Sedangkan kadar abu terendah diperoleh pada konsentrasi kapur sirih 5\% (K3) dan lama perendaman selama 25 menit (L3) sebesar 3,63.

Tabel 3. Rata-rata kadar abu keripik rebung pada taraf penambahan kapur sirih dan lama perendaman

\begin{tabular}{clll}
\hline $\begin{array}{c}\text { Konsentrasi } \\
\text { kapur sirih }\end{array}$ & \multicolumn{3}{c}{$\begin{array}{c}\text { Lama perendaman } \\
\text { (Menit) }\end{array}$} \\
\cline { 2 - 4 }$(\%)$ & L1(15) & L2(20) & L3(25) \\
\hline K1 $(1 \%)$ & 7,91 & 5,76 & 5,19 \\
K2 $(3 \%)$ & 4,34 & 5,28 & 5,17 \\
K3 $(5 \%)$ & 5,63 & 4,45 & 3,63 \\
\hline BNT $(0,05 \%)=0,29$ & &
\end{tabular}

Kadar abu diperoleh semakin lama perendaman rebung bambu maka kadar abu pada keripik rebung akan semakin rendah. Hal ini disebabkan karena lama perendaman rebung mempengaruhi banyaknya mineral yang larut dalam air. Lama waktu perendaman menyebabkan banyak komponen yang keluar dari bahan sehingga mineral yang larut dalam air semakin banyak (Prabasini ddk, 2013). Jadi, sebagian mineral yang terkandung dalam rebung terlarut kembali ke dalam air selama proses perendaman. Hal ini sesuai dengan pernyataan Siregar N.E., dkk (2015), yang menyatakan bahwa perendaman menyebabkan sebagian mineral yang terkandung dalam bahankan melarut dalam air. Hal ini yang menyebabkan kadar abu dalam keripik rebung yang dihasilkan semakin rendah.

Hasil sidik ragam menunjukkan bahwa pengaruh konsentrasi kapur sirih (K), dan lama perendaman (L) serta interaksi konsentrasi kapur sirih dan lama perendaman (KL) berpengaruh sangat nyata $(\mathrm{P} \geq 0,01)$, terhadap mutu keripik 
rebung bambu. Nilai kadar abu pada keripik rebung bambu yang dihasilkan belum memenuhi syarat mutu SNI yaitu maksimal 2,5\%. Hal ini disebabkan karena nilai kadar abu minimal yang diperoleh dari keripik rebung adalah 3,63\%.

Kadar abu mutu keripik rebung menunjukkan bahwa dari interaksi penambahan konsentrasi kapur sirih dan lama perendaman terhadap mutu keripik rebung terlihat berpengaruh sangat nyata. Hasil analisis kadar abu pada mutu keripik rebung belum memenuhi syarat SNI yaitu maksimal 2,5\%. Dimana kadar abu yang dihasilkan pada perlakuan penambahan konsentrasi kapur sirih 5\% (K3) dan lama perendaman 25 menit (L3) adalah 3,63 sehingga belum memenuhi mutu SNI keripik yang telah ditetapkan. Hal ini disebabkan karena kadar abu yang dihasilkan yaitu 3,63 melebihi dari SNI keripik yang telah diterapkan yaitu kadar abu maksimal 2,5\% .

\section{Uji Organoleptik}

\section{Aroma}

Aroma merupakan salah satu faktor penting yang mempengaruhi citarasa dan kelezatan makanan. Aroma berasal dari senyawa aroma yang merupakan senyawa yang memliki bau dan aroma. Aroma dari suatu bahan dihasilkan dari senyawa volatil (mudah menguap) yang ketika berada dalam mulut maka aroma akan terdeteksi oleh sistem pencium pada hidung. Berdasarkan hasil uji organoleptik, semakin besar penambahan kapur sirih dan semakin lama perendaman yang dilakukan maka aroma keripik rebung yang dihasilkan semakin disukai oleh panelis. Hasil sidik ragam menunjukkan bahwa pengaruh konsentrasi kapur sirih $(\mathrm{K})$, dan lama perendaman (L) serta interaksi konsentrasi kapur sirih dan lama perendaman (KL) berpengaruh tidak nyata $(\mathrm{P} \leq 0,05)$, terhadap mutu keripik rebung bambu. Nilai uji hedonik aroma tertinggi terdapat pada konsentrasi kapur sirih 3\% (K2) dan lama perendaman selama 25 menit (L3) yaitu sebesar 3,40, sedangkan nilai uji organoleptik terendah terdapat pada konsentrasi kapur sirih 1\% (K1) dan lama perendaman 15 menit (L1) yaitu sebesar 2,60 (Netral).

\section{Rasa}

Panelis yang telah mencicipi keripik rebung dari tiap perlakuan yang berbeda merasakan rasa khas keripik rebung yang tidak jauh berbeda, tidak menimbulkan rasa gatal dan getah pada keripik rebung saat dikonsumsi. Hal ini dikarenakan perendaman larutan kapur sirih dapat melarutkan getah dan menghilangkan rasa gatal yang terdapat pada keripik rebung Nilai tertinggi uji hedonik terhadap rasa keripik rebung bambu diperoleh pada perlakuan konsentrasi kapur sirih 3\% (K2) dan lama perendaman 20 menit (L2) yaitu sebesar 3,04. Sedangkan nilai rasa terendahnya diperoleh pada perlakuan penambahan kapur sirih 1\% (K1) dan lama perendaman 15 menit (L1) yaitu sebesar 2,57. Hasil analisis sidik ragam menunjukkan bahwa pengaruh konsentrasi kapur sirih (K), dan lama perendaman (L) serta interaksi konsentrasi kapur sirih dan lama perendaman (KL) berpengaruh tidak nyata $(\mathrm{P} \leq 0,05)$, terhadap mutu keripik rebung bambu. Uji organoleptik rasa menunjukkan bahwa semakin besar konsentrasi kapur sirih yang digunakan dan semakin lama perendaman yang dilakukan maka rasa keripik rebung yang dihasilkan semakin disukai oleh panelis. 


\section{Tekstur}

Tekstur adalah pengujian yang dilakukan dengan cara meraba bentukbentuk keripik tersebut. Tekstur dari keripik dapat juga menentukan kerenyahanya. Menurut Nofrianti R. (2013) kerenyahan ditentukan oleh kadar air yang terkandung di dalam keripik. Jika kadar air pada keripik tinggi, maka keripik yang dihasilkan kurang renyah dan sebaliknya. Nilai tertinggi tekstur terdapat pada konsentrasi kapur sirih sebesar 3\% (K2) dan 5\% (K3) dan lama perendaman selama 15 menit (L1) yaitu sebesar 3,04, sedangkan nilai terendah diperoleh pada konsentrasi kapur sirih 1\% (K1) dan lama perendaman 15 menit (L2) yaitu sebesar 2,44. Hasil sidik ragam menunjukkan bahwa pengaruh konsentrasi kapur sirih (K), dan Lama perendaman (L) serta interaksi konsentrasi kapur sirih dan lama perendaman (KL) berpengaruh tidak nyata $(\mathrm{P} \leq 0,05)$, terhadap mutu keripik rebung bambu. Dari hasil pengamatan dapat dinyatakan bahwa semakin besar konsentrasi kapur sirih yang digunakan dan semakin lama perendaman yang dilakukan maka tekstur keripik rebung yang dihasilkan samakin disukai panelis.

\section{KESIMPULAN}

Perlakuan terbaik berdasarkan nilai organoleptik keripik rebung terhadap aroma adalah pada penambahan kapur sirih $3 \%(\mathrm{~K} 2)$, dan lama perendaman (L3) yaitu sebesar 6,80, organopletik rasa pada penambahan konsentrasi kapur sirih 3\% (K2) dan lama perendaman 20 menit (L2) sebesar 6,07, dan organoleptik terhadap tekstur pada penambahan kapur sirih $3 \%$ (K2) dan 5\% (K3) dan lama perendaman selama 15 menit (L1) yaitu sebesar 3,04 (sangat suka).

\section{DAFTAR RUJUKAN}

Astawan, M. (2008). Sehat dengan hidangan hewani. Penebar Swadaya. Jakarta.

https://www.deherba.com/tahukah-andaberbagai-khasiat-rebung.html.

https://www.kompasiana.com/wuriehadi/rebung-sumber-panganbersahabat-di-musim-yang-takbersahabat.

Munawar. (2009). Proses pembuatan keripik rebung dengan menggunakan vacuum fraying. (Skripsi). Fakultas Teknologi Pertanian. Universitas Serambi Mekkah. Banda Aceh.

Nofrianti R.(2013). Metode freeze drying bikin keripik makin crunchy. Jurnal Aplikasi Teknologi Pangan. Vol. 2. No.1.

http. Pamungkas. (2009). Sejuta Manfaat Rebung.(Online) (http://id.shvoong .com).

Prabasini ddk. (2013). Komponen Air Dalam Tanaman. Penebar Swadaya. Jakarta

Rizkiyani N., R. Kamal, Y. H. Hamid, (2016). Pengaruh Penambahan Rebung Betung (Dendrocalamus Asper) Terhadap Karakteristik Organoleptik Dan Tingkat Penerimaan Konsumen Pada Kerupuk. Jurnal Ilmiah Mahasiswa Pendidikan Kesejahteraan Keluarga. Vol: 1 No: 1. Hal: $25-31$.

Siregar N.E., Setyohadi, M. Nurminah (2015). Pengaruh Konsentrasi Kapur Sirih (Kalsium Hidroksida) Dan Lama Perendaman Terhadap Mutu Keripik Biji Durian. Jurnal Rekayasa Pangan dan Pertanian. Vol. 3. No.2

SNI 01-2891-1996. Penentuan Kadar air. 
SNI 01-2891-1996. Penentuan Kadar Abu.

Soediaetama (2002). Pengolahan Bahan

Pangan. Penebar Swadaya. Jakarta.
Suprapti LM. (2005). Keripik, Manisan Kering, dan Sirup Nangka. Kanisius. Yogyakarta. 